\title{
MENGKAJI PERILAKU HARGA KOMODITI PANGAN DI KOTA PALU MENGGUNAKAN METODE BACKPROPAGATION
}

\author{
I. N. Peole ${ }^{1}$, R. Ratianingsih² , dan D. Lusiyanti ${ }^{3}$ \\ 1,2,3Program Studi Matematika Jurusan Matematika FMIPA Universitas Tadulako \\ Jalan Soekarno-Hatta Km. 09 Tondo, Palu 94118, Indonesia. \\ 1indryanipeole@gmail.com, 2ratianingsih@yahoo.com, 3Desylusiyanti@yahoo.com
}

\begin{abstract}
Artificial neural network is an information processing paradigm that is inspired by biological neural cell systems, like the brain, that processes information. The purpose of this research is to develop neural networks to predict the price of food commodities using backpropagation method. The research was conducted by using the rate of monthly price of food commodities in Palu from January 2011 - December 2015. The data is used to predict food commodity prices forduring 2016. The backpropagation networks consists of three layers. The first layer of input is constructedin the form of monthly prices of IR 64 , ciherang, membramo, cimandi, superwin, sintanur, cisantana, sticky black, sticky white, yellow corn dry, white corn, soybeans, peanuts, green beans, cassava, sweet potato, onion, garlic, red pepper large, red pepper curls, cayenne pepper, cabbage round, potatoes, tomatoes, carrots, cauliflower, beans, onion, avocado, red apples, green apples, oranges, jackfruit, mango, pineapple, papaya, banana, banana horns, rambutan, bark, olive, durian, watermelon, and mangosteen from January - December that consist of 12 variables. One hidden layer consistof five neurons and the other one is the output, that is the food commodity prices. The training process shows that on a maximum iterations on 500 , constant learning rate 0,3 and 0,6 momentum, the predictions have $97.92 \%$ of level accuracy. The identification resultof food commodity prices behavior in Palu is predicted as follow: IR 64 Rp7.387, ciherang Rp8.182, membramo Rp8.150, cimandi Rp8.131, superwin Rp8.228, sintanur Rp8.660, cisantana Rp8.122, black sticky rice Rp21.383, white sticky rice Rp16.558, dry yellow corn Rp5.983, white corn Rp9.283, soybeans Rp14.600, peanuts Rp20.008, green beans Rp16.375, cassava Rp8.225, sweet potato Rp8. 542, red onion Rp28.550, garlic Rp21.208, red chili Rp27.308, curly red chili Rp23.650, cayenne Rp36.450, round cabbage Rp6.833, Rp12.067 potatoes, tomatoes Rp6.108, carrots 11.000, cauliflower Rp8.625, beans Rp10.333, scallion Rp25.242, avocado 11.000, red apple Rp29.023, green apple Rp31.067, orange Rp6.083, jackfruit Rp23.483, mango Rp11.187, pineapple Rp8.183, papaya Rp10.600, bananas Rp8.481, horn banana Rp2.683, rambutan Rp8.450, barking Rp5.625, tan Rp8.366, durian Rp19.208, watermelon Rp14.528 and mangosteen Rp18.067. It is predicted that the food commodity prices increased monthly.
\end{abstract}

Keywords $\quad$ : Accuracy, Backpropagation, Food Commodity, Neural Network, Prediction.

\section{ABSTRAK}

jaringan saraf tiruan adalah paradigma pemrosesan informasi yang terinspirasi oleh sistem sel saraf biologis, seperti otak yang memproses informasi. Tujuan dari penelitian ini adalah untuk mengembangkan jaringan saraf untuk memprediksi harga komoditas pangan menggunakan metode backpropagation. Penelitian ini dilakukan 
dengan menggunakan tingkat harga bulanan komoditas pangan di Palu dari Januari 2011 - Desember 2015. Data tersebut digunakan untuk memprediksi harga komoditas pangan untuk selama 2016. Jaringan backpropagation terdiri dari tiga lapisan. Lapisan pertama masukan dibangun dalam bentuk harga bulanan IR 64 , ciherang, membramo, cimandi, superwin, sintanur, cisantana, ketan hitam, lengket putih, kuning jagung kering, jagung putih, kedelai, kacang tanah, kacang hijau, ubi kayu , ubi jalar, bawang merah, bawang putih, cabai merah besar, ikal cabai merah, cabai rawit, putaran kubis, kentang, tomat, wortel, kembang kol, kacang-kacangan, bawang, alpukat, apel merah, apel hijau, jeruk, nangka, mangga, nanas, pepaya, pisang, tanduk pisang, rambutan, kulit kayu, zaitun, durian, semangka, dan manggis dari Januari-Desember yang terdiri dari 12 variabel. Satu lapisan tersembunyi terdiri dari lima neuron dan yang lain adalah output, yang merupakan harga komoditas pangan. Pada proses pelatihan didapatkan hasil maksimal pada iterasi 500, tingkat pembelajaran konstan 0,3 dan 0,6 momentum, prediksi memiliki 97,92\% tingkat akurasi. Hasil identifikasi perilaku harga komoditas pangan di Kota Palu yang didapatkan adalah IR 64 Rp7.387, ciherang Rp8.182, membramo Rp8.150, cimandi Rp8.131, superwin Rp8.228, sintanur Rp8.660, cisantana Rp8.122, pulut hitam Rp21.383, pulut putih Rp16.558, jagung kuning kering Rp5.983, jagung putih Rp9.283, kedelai Rp14.600, kacang tanah Rp20.008, kacang hijau Rp16.375, ubi kayu Rp8.225, ubi jalar Rp8.542, bawang merah Rp28.550, bawang putih Rp21.208, cabe merah besar Rp27.308, cabe merah keriting Rp23.650, cabe rawit Rp36.450, kol bulat Rp6.833, kentang Rp12.067, tomat Rp6.108, wortel Rp11.000, bunga kol Rp8.625, buncis Rp10.333, bawang daun Rp25.242, alpokat Rp11.000, apel merah Rp29.023, apel hijau Rp31.067, jeruk Rp6.083, nangka Rp23.483, mangga Rp11.187, nenas Rp8.183, pepaya Rp10.600, pisang ambon Rp8.481, pisang tanduk Rp2.683, rambutan Rp8.450, salak Rp5.625, langsat Rp8.366, durian Rp19.208, semangka Rp14.528, dan manggis Rp18.067. Diperkirakan bahwa harga komoditas pangan meningkat tiap bulan.

Kata Kunci $\quad$ : Akurasi, Backpropagation, Jaringan Syaraf Tiruan, Komoditi Pangan, Prediksi.

\section{LATAR BELAKANG}

\subsection{Latar Belakang}

Tanaman pangan merupakan segala sesuatu yang bersumber dari sumber hayati dan air, baik yang diolah maupun yang tidak diolah. Pangan merupakan komoditas strategis dan bahkan sering dikaitkan dengan aspek politis diberbagai negara termasuk Indonesia.Pangan diperuntukan bagi manusia sebagai makanan atau minuman serta juga termasuk bahan tambahan pangan, bahan baku pangan juga bahan- bahan lain yang dapat digunakan dalam proses penyiapan, pengolahan atau pembuatan makan dan minuman.Sedangkan untuk komoditas pangan harus mengandung zat gizi yang terdiri dari karbohidrat, protein, lemak serta vitamin dan juga mineral yang memiliki manfaat bagi pertumbuhan serta kesehatan manusia. Komoditas pangan adalah segala hal yang dapat untuk dikonsumsi berasal dari tanah dan memerlukan bantuan air serta sumber hayati yang terdapat didalamya dan dapat digunakan oleh manusia sebagai bahan makanan. Komoditi pangan tersebut terdiri dari IR 64, ciherang, membramo, cimandi, superwin, sinta nur, cisantana, pulut hitam, pulut putih, jagung kuning kering, jagung putih, kedelai, kacang tanah, kacang hijau, ubi kayu, ubi jalar, bawang merah, bawang putih, cabe merah besar, cabe merah keriting, cabe rawit, kol bulat, kentang, tomat, wortel, bunga kol, buncis, bawang daun, alpokat, apel merah, apel hijau, 
jeruk, nangka, mangga, nenas, pepaya, pisang ambon, pisang tanduk, rambutan, salak, langsat, durian, semangka dan manggis.

Di sektor pertanian, setiap aktivitas proses produksi selalu dihadapkan dengan situasi resiko dan ketidakpastian. Sumber ketidakpastian yang penting di sektor pertanian adalah fluktuasi produksi pertanian dan fluktuasi harga (Soekartawi dkk., 1993). Ada beberapa faktor yang mendasari ketidakstabilan harga seperti faktor cuaca ekstrem yang membuat petani sulit atau bahkan gagal panen sehingga stok tidak dapat dipenuhi. Ditinjau dari iklimnya, ada bulan - bulan dimana curah hujan yang sangat tinggi menyebabkan banjir dimana-mana ataupun musim panas yang berkepanjangan yang pada akhirnya banyak menyebabkan gagal panen dan mengganggu ketersediaan stok. Terganggunya ketersediaan stok memberikan pengaruh terhadap permintaan yang berimbas pada ketidakstabilan harga. Ketidakstabilan harga inilah yang memicu terjadinya inflasi (Oner C. 2012).

Penelitian ini akan melakukan prediksi harga komoditi pangan di Kota Palu untuk dapat meminimalisir resiko dari ketidakstabilan fluktuasi harga yang berdampak pada ketidakstabilan perekonomian dengan menggunakan Jaringan Syaraf Tiruan. Jaringan Syaraf Tiruan (JST) merupakan salah satu representasi buatan dari otak manusia yang selalu mencoba untuk mensimulasikan proses pembelajaran pada otak manusia (Kusumadewi S., 2004). Prediksi harga komoditi pangan akan diprediksi menggunakan metode backpropagation. Metode backpropagation mampu meramalkan apa yang terjadi dimasa lampau atau faktor-faktor yang terkait. Backpropagation juga memiliki kemampuan dalam meminimalisir kesalahan peramalan dengan cara merambat kembali error (kesalahan peramalan) yang berasal dari lapisan output kembali kelapisan input secara berulang-ulang hingga mendapatkan nilai error terkecil dan hasil prediksi yang baik.

\subsection{Batasan Masalah}

Batasan masalah dari penelitian ini adalah data prediksi harga yang digunakan data bulanan dari tahun $2011-2015$.

\section{METODE PENELITIAN}

Penelitian ini dilakukan sesuai dengan prosedur dibawah ini :

1. Melakukan studi literatur

2. Menganalisa Masalah

3. Mengumpulkan beberapa data dari berbagai sumber yang ada

4. Penerapan metode backpropagation pada pola pengenalan dan membuat program pada matlab.

5. Melakukan proses training dan testing pada data

6. Setelah hasil dari contoh kasus diperoleh kemudian akan diberi penjelasan atas hasil yang di dapat kemudian disimpulkan. 


\section{HASIL DAN PEMBAHASAN}

\subsection{Pengumpulan Data}

Data penelitian diperoleh dari kantor Dinas Pertanian Provinsi Sulawesi Tengah.Data tersebut adalah data harga komoditi pangan yang terdiri dari 44 komoditi, yaitu IR 64, ciherang, membramo, cimandi, superwin, sintanur, cisantana, pulut hitam, pulut putih, jagung kuning kering, jagung putih, kedelai, kacang tanah, kacang hijau, ubi kayu, ubi jalar, bawang merah, bawang putih, cabe merah besar, cabe merah keriting, cabe rawit, kol bulat, kentang, tomat, wortel, bunga kol, buncis, bawang daun, alpokat, apel merah, apel hijau, jeruk, nangka, mangga, nenas, pepaya, pisang ambon, pisang tanduk, rambutan, salak, langsat, durian, semangka, dan manggis.

Data 44 komoditi pangan tersebut sebanyak 220 data yang diambil dari tahun 2011 2015. Sebelum data diolah, terlebih dahulu data dibagi menjadi dua bagian yaitu data training dan data testing dengan menggunakan presentasi $80: 20$, artinya $80 \%$ data total 220 data yaitu 176 akan dijadikan sebagai data training dan $20 \%$ dari total 220 data yaitu 44 akan dijadikan sebagai data testing.

\subsection{Normalisasi Data / Scaling}

Normalisasi / scaling (perubahan rentang dari nilai atribut) atribut bernilai bilangan real umumnya juga diperlukan agar proses perhitungan lebih mudah dan memberi jaminan bahwa atribut yang rentang nilainya lebih kecil. Normalisasi umumnya memberikan hasil yang lebih baik. Rentang nilai atribut yang dianjurkan untuk digunakan adalah $[0,1]$ atau $[-1,+1](\mathrm{Hsu}, \mathrm{C}$, W, 2004).

Normalisasi dalam rentang nilai $[0,1]$ menghasilkan akurasi yang sama dengan $[-1,+1]$, tetapi waktu komputasi yang dibutuhkan mungkin berbeda (Sembiring, K, 2007).Normalisasi yang dilakukan pada training data, harus dilakukan juga dengan cara yang sama terhadap testing data. Adapun rumus normalisasi pada program matlab sebagai berikut :

$$
\text { Xnew }=(x-\operatorname{ones}(R, 1) * \text { mean }(x)) \cdot /(\text { ones }(48,1) * \operatorname{std}(x))
$$

Tabel 1 : Hasil Normalisasi Data

\begin{tabular}{|c|c|c|c|c|c|c|c|c|c|c|c|c|}
\hline & $\mathrm{X}_{1}$ & $\mathrm{X}_{2}$ & $\mathrm{X}_{3}$ & $\mathrm{X}_{4}$ & $\mathrm{X}_{5}$ & $\mathrm{X}_{6}$ & $\mathrm{X}_{7}$ & $\mathrm{X}_{8}$ & $\mathrm{X}_{9}$ & $\mathrm{X}_{10}$ & $\mathrm{X}_{11}$ & $\mathrm{X}_{12}$ \\
\hline 1 & $-0,79$ & $-0,85$ & $-0,78$ & $-0,73$ & $-0,75$ & $-0,85$ & $-0,70$ & $-0,70$ & $-0,72$ & $-0,75$ & $-0,68$ & $-0,76$ \\
\hline 2 & $-0,62$ & $-0,63$ & $-0,59$ & $-0,61$ & $-0,60$ & $-0,63$ & $-0,57$ & $-0,55$ & $-0,59$ & $-0,65$ & $-0,61$ & $-0,63$ \\
\hline 3 & $-0,62$ & $-0,63$ & $-0,59$ & $-0,58$ & $-0,60$ & $-0,63$ & $-0,59$ & $-0,57$ & $-0,59$ & $-0,62$ & $-0,59$ & $-0,63$ \\
\hline 4 & $-0,60$ & $-0,61$ & $-0,57$ & $-0,56$ & $-0,58$ & $-0,61$ & $-0,57$ & $-0,55$ & $-0,67$ & $-0,83$ & $-0,67$ & $-0,69$ \\
\hline 5 & $-0,67$ & $-0,69$ & $-0,64$ & $-0,64$ & $-0,66$ & $-0,73$ & $-0,74$ & $-0,62$ & $-0,64$ & $-0,62$ & $-0,65$ & $-0,69$ \\
\hline 6 & $-0,60$ & $-0,61$ & $-0,57$ & $-0,56$ & $-0,75$ & $-0,79$ & $-0,70$ & $-0,65$ & $-0,67$ & $-0,75$ & $-0,68$ & $-0,74$ \\
\hline 7 & $-0,60$ & $-0,61$ & $-0,57$ & $-0,56$ & $-0,58$ & $-0,61$ & $-0,57$ & $-0,55$ & $-0,57$ & $-0,62$ & $-0,59$ & $-0,63$ \\
\hline 8 & $-0,60$ & $-0,61$ & $-0,57$ & $-0,56$ & $-0,58$ & $-0,61$ & $-0,57$ & $-0,55$ & $-0,57$ & $-0,62$ & $-0,59$ & $-0,63$ \\
\hline 9 & $-0,60$ & $-0,61$ & $-0,57$ & $-0,56$ & $-0,58$ & $-0,61$ & $-0,57$ & $-0,55$ & $-0,62$ & $-0,80$ & $-0,63$ & $-0,59$ \\
\hline
\end{tabular}




\begin{tabular}{|c|c|c|c|c|c|c|c|c|c|c|c|c|}
\hline 1 & $-0,51$ & $-0,43$ & $-0,15$ & $-0,44$ & $-0,40$ & $-0,49$ & $-0,47$ & $-0,45$ & $-0,18$ & $-0,22$ & $-0,48$ & $-0,51$ \\
0 & & $\vdots$ & $\vdots$ & $\vdots$ & $\vdots$ & $\vdots$ & $\vdots$ & $\vdots$ & $\vdots$ & $\vdots$ & $\vdots$ & $\vdots$ \\
\hline$\vdots$ & $\vdots$ & $\vdots$ & & & & & & & & & & \\
2 & 1,01 & 0,21 & $-0,15$ & $-0,79$ & $-0,58$ & $-0,61$ & $-0,57$ & $-0,55$ & 0,59 & 0,08 & $-0,06$ & $-0,04$ \\
0 & & & & & & & & & & & & \\
\hline
\end{tabular}

\subsection{Pembentukan Arsitektur Jaringan}

Dalam membentuk arsitektur jaringan syaraf tiruan dibentuk pola-pola hubungan antara neuron. Neuron-neuron tersebut akan mentransformasikan informasi yang diterima melalui sambungan keluarnya menuju ke neuron-neuron yang lain. Pada jaringan syaraf, hubungan ini dikenal dengan nama bobot dan bias. Adapun arsitektur jaringan yang digunakan dalam penelitian ini adalah sebagai berikut :

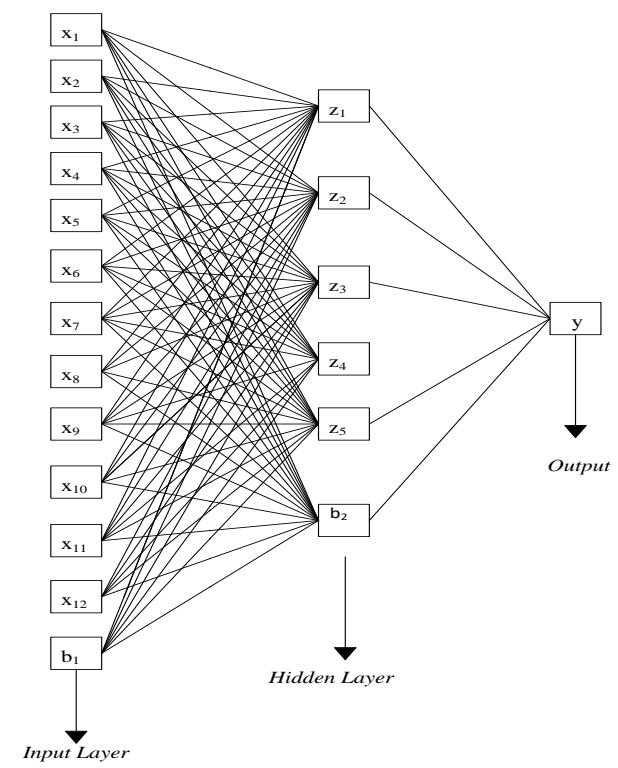

Gambar 1 : Arsitektur Jaringan Syaraf Tiruan

\subsection{Pengolahan Data Menggunakan Program Matlab dengan Metode Backpropagation}

\subsubsection{Pelatihan data (Training)}

Pelatihan data digunakan untuk membangun model jaringan. Pelatihan data dilakukan beberapa kali trial and error untuk mendapatkan jaringan terbaik dengan menentukan jumlah neuron. Uji coba yang dilakukan menggunakan data training untuk 1 komoditi pangan berukuran $48 \times 12$. 48 adalah jumlah data dan 12 adalah faktor harga yang dijadikan sebagai atribut untuk dapat memprediksi harga.

Proses training dapat ditampilkan pada Gambar 2. 


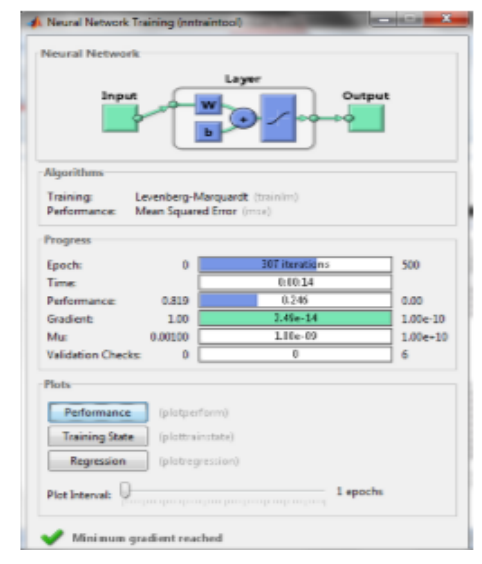

Gambar 2 : Proses pelatihan data pada matlab 2010

Keberhasilan proses training diperlihatkan di performance yang ditampilkan pada Gambar 3. Gambar tersebut memperlihatkan hasil grafik MSE yang terjadi pada proses pelatihan.

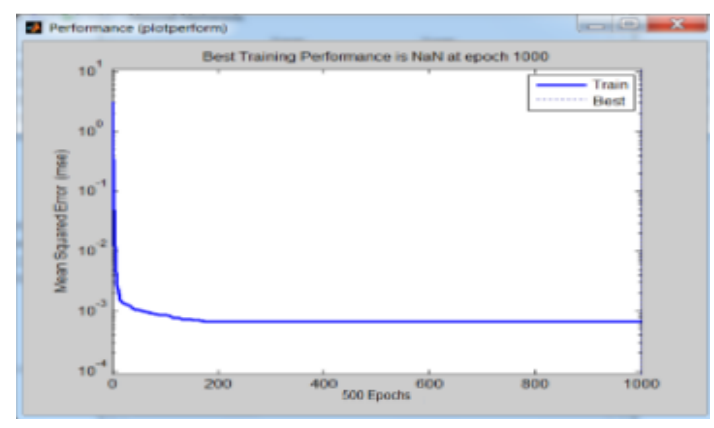

Gambar 3 : Performance

Selanjutnya pada Gambar 4 memperlihatkan hasil dari pelatihan data yang menghasilkan yt dimana yt adalah hasil prediksi.

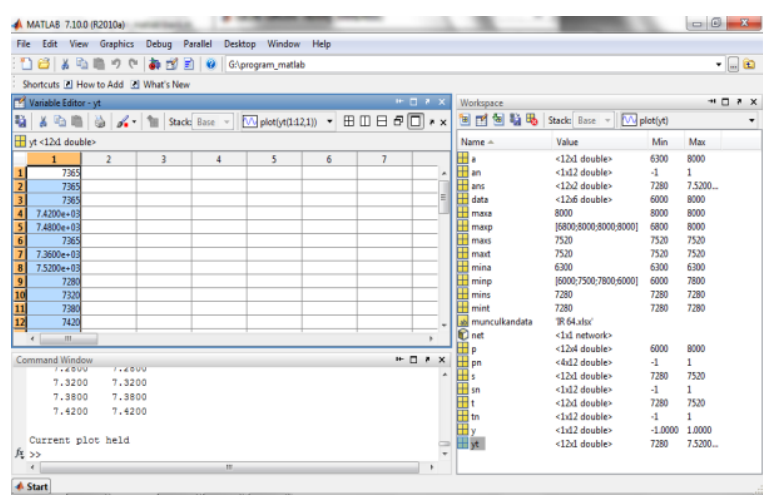

Gambar 4 : Hasil Prediksi dari Pelatihan Data 


\subsubsection{Pengujian Data (testing)}

Pengujian data merupakan tahapan dimana sistem mulai melakukan proses prediksi harga komoditi pangan. Input data yang akan diuji adalah yang memiliki faktor harga yang sama dengan data pelatihan. Pengujian dilakukan menggunakan rancangan arsitektur terbaik yang telah diperoleh dari hasil pelatihan, struktur jaringan yang digunakan terdiri dari satu lapis yang berisi 12 neuron input. Lapisan tersembunyi pertama terdiri dari 5 neuron dan lapisan output terdiri dari 1 neuron.

Tabel 2 : Hasil perbandingan prediksi dan data aktual untuk beras IR 64

\begin{tabular}{|c|c|c|c|}
\hline Bulan & $\begin{array}{c}\text { Prediksi } \\
\text { Output }\end{array}$ & $\begin{array}{c}\text { Data Aktual dari Kantor Dinas } \\
\text { Pertanian Sulawesi Tengah } \\
\text { untuk beras IR 64 }\end{array}$ & $\begin{array}{c}\text { Persentase } \\
\text { kesalahan } \\
\text { prediksi (\%) }\end{array}$ \\
\hline Januari & 7.3950 & 7.3800 & 0,20 \\
\hline Februari & 7.3950 & 7.3800 & 0,20 \\
\hline Maret & 7.3950 & 7.3800 & 0,20 \\
\hline April & 7.4200 & 7.4200 & - \\
\hline Mei & 7.4800 & 7.4800 & - \\
\hline Juni & 7.3650 & 7.3200 & -61 \\
\hline Juli & 7.3600 & 7.3600 & - \\
\hline Agustus & 7.5200 & 7.5200 & - \\
\hline September & 7.2800 & 7.2800 & - \\
\hline Oktober & 7.3200 & 7.3200 & - \\
\hline November & 7.3800 & 7.3800 & $0,10083 \%$ \\
\hline Desember & 7.4200 & 7.4200 & \\
\hline & Rata - rata kesalahan & \\
\hline
\end{tabular}

Dari Tabel 2 dapat dilihat rata-rata kesalahan hasil simulasi prediksi harga menggunakan Jaringan Syaraf Tiruan pada periode Januari - Desember adalah sebesar 0,10083\%. Untuk 1 komoditi pangan beras IR 64 dengan keakuratan prediksinya adalah 99,89\%. Perbandingan hasil prediksi dan data aktual ditampilkan pula dalam Gambar 6. 


\section{Rp7.600}

Rp7.500

Rp7.400

Rp7.300

Rp7.200

Rp7.100

$$
\begin{array}{llllllllllll}
1 & 2 & 3 & 4 & 5 & 6 & 7 & 8 & 9 & 10 & 11 & 12
\end{array}
$$

Gambar 6 : Perbandingan Hasil Prediksi dan Aktual untuk beras IR 64

Peramalan ini menggunakan JST terbaik dengan rancangan yang didapatkan pada trial and error di pelatihan data dengan learning rate 0,3 momentum constant 0,6 fungsi aktivasi logsig untuk hidden layer dan purelin untuk output layer.Kita dapat melihat hasil prediksi harga pasar komoditi pangan serta perilaku musiman tiap harga komoditi pasar untuk 3 bulan pertama ditahun 2016 pada tabel berikut.

Tabel 3 : Peramalan Harga Komoditi Pangan untuk Tahun 2016

\begin{tabular}{|c|c|c|c|c|c|c|c|c|c|c|}
\hline \multirow[t]{2}{*}{ Komoditi Pangan } & \multicolumn{3}{|c|}{$\begin{array}{c}\text { Hasil JST } \\
\text { Prediksi Harga (Rp) }\end{array}$} & \multicolumn{3}{|c|}{$\begin{array}{l}\text { Data Aktual dari Kantor } \\
\text { Dinas Pertanian Sulawesi } \\
\text { Tengah } \\
\text { (Rp) }\end{array}$} & \multicolumn{3}{|c|}{ Akurasi Prediksi (\%) } & \multirow{2}{*}{$\begin{array}{l}\text { Rata- } \\
\text { rata } \\
\text { Akurasi } \\
(\%)\end{array}$} \\
\hline & Jan & Feb & Mar & Jan & Feb & Mar & Jan & Feb & Mar & \\
\hline IR 64 & 7.395 & 7.395 & 7.395 & 7.380 & 7.380 & 7.380 & 99,8 & $\begin{array}{c}99 \\
8\end{array}$ & 99,8 & 99,8 \\
\hline Ciherang & 8.375 & 8.375 & 9.225 & 8.200 & 8.300 & 8.800 & 97,8 & $\begin{array}{c}99 \\
1\end{array}$ & 95,1 & 97,3 \\
\hline Membramo & 8.239 & 8.434 & 8.434 & 8.240 & 8.300 & 8.800 & 99,9 & $\begin{array}{c}98 \\
3\end{array}$ & 95,8 & 98 \\
\hline Cimandi & 8.194 & 8.170 & 8.170 & 8.100 & 8.080 & 8.580 & 98,8 & $\begin{array}{c}98 \\
8\end{array}$ & 95,2 & 97,6 \\
\hline Superwin & 8.000 & 8.250 & 8.450 & 8.000 & 8.100 & 8.700 & 100 & $\begin{array}{c}98 \\
1\end{array}$ & 97,1 & 98,4 \\
\hline Sintanur & 8.773 & 8.773 & 8.773 & 8.540 & 8.640 & 9.140 & 97,2 & $\begin{array}{c}98 \\
4\end{array}$ & 95,9 & 97,1 \\
\hline Cisantana & 8.076 & 8.076 & 8.242 & 7.860 & 8.060 & 8.660 & 97,2 & $\begin{array}{c}99 \\
8\end{array}$ & 95,1 & 97,3 \\
\hline Pulut Hitam & $\begin{array}{c}20.80 \\
0\end{array}$ & $\begin{array}{c}20.40 \\
0\end{array}$ & $\begin{array}{c}19.60 \\
0\end{array}$ & $\begin{array}{c}20.80 \\
0\end{array}$ & $\begin{array}{c}20.40 \\
0\end{array}$ & $\begin{array}{c}19.60 \\
0\end{array}$ & 100 & 100 & 100 & 100 \\
\hline Pulut Putih & $\begin{array}{c}17.00 \\
0\end{array}$ & $\begin{array}{c}17.00 \\
0\end{array}$ & $\begin{array}{c}16.80 \\
0\end{array}$ & $\begin{array}{c}17.00 \\
0\end{array}$ & $\begin{array}{c}17.00 \\
0\end{array}$ & $\begin{array}{c}16.80 \\
0\end{array}$ & 100 & 100 & 100 & 100 \\
\hline $\begin{array}{l}\text { Jagung Kuning } \\
\text { Kering }\end{array}$ & 5.400 & 5.400 & 6.600 & 5.400 & 5.400 & 6.600 & 100 & 100 & 100 & 100 \\
\hline Jagung Putih & 8.400 & 8.400 & 9.600 & 8.400 & 8.400 & 9.600 & 100 & 100 & 100 & 100 \\
\hline Kedelai & $\begin{array}{c}15.40 \\
0\end{array}$ & $\begin{array}{c}15.40 \\
0\end{array}$ & $\begin{array}{c}13.60 \\
0\end{array}$ & $\begin{array}{c}15.40 \\
0\end{array}$ & $\begin{array}{c}15.40 \\
0\end{array}$ & $\begin{array}{c}13.60 \\
0\end{array}$ & 100 & 100 & 100 & 100 \\
\hline Kacang Tanah & $\begin{array}{c}19.80 \\
0\end{array}$ & $\begin{array}{c}19.00 \\
0\end{array}$ & $\begin{array}{c}18.20 \\
0\end{array}$ & $\begin{array}{c}19.80 \\
0\end{array}$ & $\begin{array}{c}19.00 \\
0\end{array}$ & $\begin{array}{c}18.20 \\
0\end{array}$ & 100 & 100 & 100 & 100 \\
\hline
\end{tabular}




\begin{tabular}{|c|c|c|c|c|c|c|c|c|c|c|}
\hline Kacang Hijau & $\begin{array}{c}15.60 \\
0\end{array}$ & $\begin{array}{c}15.60 \\
0\end{array}$ & $\begin{array}{c}16.00 \\
0\end{array}$ & $\begin{array}{c}15.60 \\
0\end{array}$ & $\begin{array}{c}15.60 \\
0\end{array}$ & $\begin{array}{c}16.00 \\
0\end{array}$ & 100 & 100 & 100 & 100 \\
\hline Ubi Kayu & 9.000 & 9.000 & 8.001 & 9.000 & 9.000 & 8.000 & 100 & 100 & 99,9 & 99,96 \\
\hline Ubi Jalar & 9.000 & 9.000 & 8.000 & 9.000 & 9.000 & 8.000 & 100 & 100 & 100 & 100 \\
\hline Bawang Merah & $\begin{array}{c}26.10 \\
0\end{array}$ & $\begin{array}{c}26.00 \\
0\end{array}$ & $\begin{array}{c}28.58 \\
4\end{array}$ & $\begin{array}{c}26.10 \\
0\end{array}$ & $\begin{array}{c}26.00 \\
0\end{array}$ & $\begin{array}{c}28.60 \\
0\end{array}$ & 100 & 100 & 99,9 & 99,96 \\
\hline Bawang Putih & $\begin{array}{c}21.70 \\
0\end{array}$ & $\begin{array}{c}24.20 \\
0\end{array}$ & $\begin{array}{c}25.20 \\
0\end{array}$ & $\begin{array}{c}21.70 \\
0\end{array}$ & $\begin{array}{c}24.20 \\
0\end{array}$ & $\begin{array}{c}25.20 \\
0\end{array}$ & 100 & 100 & 100 & 100 \\
\hline $\begin{array}{l}\text { Cabe Merah } \\
\text { Besar }\end{array}$ & $\begin{array}{c}30.60 \\
0\end{array}$ & $\begin{array}{c}22.80 \\
0\end{array}$ & $\begin{array}{c}24.00 \\
0\end{array}$ & $\begin{array}{c}30.60 \\
0\end{array}$ & $\begin{array}{c}22.80 \\
0\end{array}$ & $\begin{array}{c}24.00 \\
0\end{array}$ & 100 & 100 & 100 & 100 \\
\hline $\begin{array}{l}\text { Cabe Merah } \\
\text { Keriting }\end{array}$ & $\begin{array}{c}27.80 \\
0\end{array}$ & $\begin{array}{c}17.40 \\
0\end{array}$ & $\begin{array}{c}20.40 \\
0\end{array}$ & $\begin{array}{c}27.80 \\
0\end{array}$ & $\begin{array}{c}17.40 \\
0\end{array}$ & $\begin{array}{c}20.40 \\
0\end{array}$ & 100 & 100 & 100 & 100 \\
\hline Cabe Rawit & $\begin{array}{c}41.40 \\
0\end{array}$ & $\begin{array}{c}27.00 \\
0\end{array}$ & $\begin{array}{c}40.80 \\
0\end{array}$ & $\begin{array}{c}41.40 \\
0\end{array}$ & $\begin{array}{c}27.00 \\
0\end{array}$ & $\begin{array}{c}40.80 \\
0\end{array}$ & 100 & 100 & 100 & 100 \\
\hline Kol Bulat & 7.400 & 7.000 & 5.600 & 7.400 & 7.000 & 5.600 & 100 & 100 & 100 & 100 \\
\hline Kentang & $\begin{array}{c}11.00 \\
0\end{array}$ & $\begin{array}{c}10.60 \\
0 \\
\end{array}$ & $\begin{array}{c}11.60 \\
0 \\
\end{array}$ & $\begin{array}{c}11.00 \\
0 \\
\end{array}$ & $\begin{array}{c}10.60 \\
0 \\
\end{array}$ & $\begin{array}{c}11.60 \\
0 \\
\end{array}$ & 100 & 100 & 100 & 100 \\
\hline Tomat & 5.400 & 5.000 & 5.700 & 5.400 & 5.000 & 5.700 & 100 & 100 & 100 & 100 \\
\hline Wortel & $\begin{array}{c}13.90 \\
0 \\
\end{array}$ & $\begin{array}{c}10.10 \\
0 \\
\end{array}$ & $\begin{array}{c}10.90 \\
0 \\
\end{array}$ & $\begin{array}{c}13.90 \\
0 \\
\end{array}$ & $\begin{array}{c}10.10 \\
0 \\
\end{array}$ & $\begin{array}{c}10.90 \\
0 \\
\end{array}$ & 100 & 100 & 100 & 100 \\
\hline Bunga Kol & 7.600 & 6.600 & 8.400 & 7.600 & 6.600 & 8.400 & 100 & 100 & 100 & 100 \\
\hline Buncis & 8.600 & 8.000 & 9.600 & 8.600 & 8.000 & 9.600 & 100 & 100 & 100 & 100 \\
\hline Bawang daun & $\begin{array}{c}25.00 \\
0 \\
\end{array}$ & $\begin{array}{c}22.60 \\
0 \\
\end{array}$ & $\begin{array}{c}22.60 \\
0 \\
\end{array}$ & $\begin{array}{c}25.00 \\
0 \\
\end{array}$ & $\begin{array}{c}22.60 \\
0 \\
\end{array}$ & $\begin{array}{c}22.60 \\
0 \\
\end{array}$ & 100 & 100 & 100 & 100 \\
\hline Alpokat & $\begin{array}{c}11.20 \\
0\end{array}$ & $\begin{array}{c}11.20 \\
0\end{array}$ & 8.400 & $\begin{array}{c}12.40 \\
0\end{array}$ & $\begin{array}{c}10.20 \\
0\end{array}$ & 8.000 & 90,3 & $\begin{array}{c}90 \\
1 \\
\end{array}$ & 95 & 91,8 \\
\hline Apel Merah & $\begin{array}{c}27.72 \\
1\end{array}$ & $\begin{array}{c}27.72 \\
1 \\
\end{array}$ & $\begin{array}{c}27.72 \\
1 \\
\end{array}$ & $\begin{array}{c}28.00 \\
0\end{array}$ & $\begin{array}{c}29.00 \\
0\end{array}$ & $\begin{array}{c}28.00 \\
0\end{array}$ & 99,1 & $\begin{array}{c}95 \\
5 \\
\end{array}$ & 99,1 & 97,9 \\
\hline Apel Hijau & $\begin{array}{c}31.06 \\
7\end{array}$ & $\begin{array}{c}31.06 \\
7\end{array}$ & $\begin{array}{c}31.06 \\
7\end{array}$ & $\begin{array}{c}31.00 \\
0\end{array}$ & $\begin{array}{c}32.00 \\
0\end{array}$ & $\begin{array}{c}28.60 \\
0\end{array}$ & 97,4 & $\begin{array}{c}99 \\
3\end{array}$ & 99,7 & 98,8 \\
\hline Jeruk & 6.083 & 6.083 & 6.083 & 5.500 & 5.500 & 6.500 & 100 & 100 & 98,4 & 99,4 \\
\hline Nangka & $\begin{array}{c}24.38 \\
2 \\
\end{array}$ & $\begin{array}{c}22.99 \\
9 \\
\end{array}$ & $\begin{array}{c}22.08 \\
8 \\
\end{array}$ & $\begin{array}{c}26.00 \\
0 \\
\end{array}$ & $\begin{array}{c}23.00 \\
0 \\
\end{array}$ & $\begin{array}{c}22.00 \\
0 \\
\end{array}$ & 93,7 & $\begin{array}{c}99 \\
9 \\
\end{array}$ & 99,6 & 97,7 \\
\hline Mangga & $\begin{array}{c}10.74 \\
4 \\
\end{array}$ & $\begin{array}{c}10.74 \\
4 \\
\end{array}$ & $\begin{array}{c}10.71 \\
7 \\
\end{array}$ & $\begin{array}{c}12.00 \\
0\end{array}$ & $\begin{array}{c}11.60 \\
0\end{array}$ & 9.000 & 89,5 & $\begin{array}{c}92 \\
6 \\
\end{array}$ & 80,9 & 87,6 \\
\hline Nenas & 7.429 & 7.429 & 7.432 & 7.800 & 6.200 & 7.000 & 89,7 & $\begin{array}{c}87 \\
1 \\
\end{array}$ & 100 & 92,2 \\
\hline Pepaya & $\begin{array}{c}11.06 \\
7 \\
\end{array}$ & $\begin{array}{c}11.06 \\
7 \\
\end{array}$ & $\begin{array}{c}11.06 \\
7 \\
\end{array}$ & $\begin{array}{c}11.20 \\
0 \\
\end{array}$ & $\begin{array}{c}10.80 \\
0 \\
\end{array}$ & $\begin{array}{c}11.20 \\
0 \\
\end{array}$ & 98,8 & $\begin{array}{c}97 \\
5\end{array}$ & 98,8 & 98,3 \\
\hline Pisang Ambon & 8.500 & 8.500 & 8.500 & 8.600 & 7.600 & 7.600 & 93,9 & $\begin{array}{c}93 \\
6 \\
\end{array}$ & 93,6 & 93,7 \\
\hline Pisang Tanduk & 2.067 & 2.067 & 2.067 & 2.200 & 2.200 & 1.800 & 94 & 94 & 85,1 & 91,03 \\
\hline Rambutan & 8.867 & 8.867 & 8.867 & $\begin{array}{c}10.20 \\
0\end{array}$ & 9.200 & 7.200 & 87 & $\begin{array}{c}96 \\
4 \\
\end{array}$ & 76,8 & 86,7 \\
\hline Salak & 5.496 & 5.496 & 5.496 & 5.200 & 5.800 & 5.600 & 93,5 & $\begin{array}{c}94 \\
8\end{array}$ & 98,2 & 95,5 \\
\hline Langsat & 8.382 & 8.382 & 8.382 & 9.200 & 9.200 & 7.200 & 91,2 & $\begin{array}{c}91 \\
2 \\
\end{array}$ & 83,5 & 88,6 \\
\hline Durian & $\begin{array}{c}20.00 \\
0\end{array}$ & $\begin{array}{c}20.00 \\
0\end{array}$ & $\begin{array}{c}20.00 \\
0\end{array}$ & $\begin{array}{c}21.00 \\
0\end{array}$ & $\begin{array}{c}21.00 \\
0\end{array}$ & $\begin{array}{c}18.00 \\
0\end{array}$ & 95,3 & $\begin{array}{c}95 \\
3 \\
\end{array}$ & 88,8 & 93,1 \\
\hline Semangka & $\begin{array}{c}15.59 \\
2 \\
\end{array}$ & $\begin{array}{c}15.59 \\
2 \\
\end{array}$ & $\begin{array}{c}15.59 \\
2 \\
\end{array}$ & $\begin{array}{c}17.00 \\
0\end{array}$ & $\begin{array}{c}14.00 \\
0\end{array}$ & $\begin{array}{c}14.60 \\
0\end{array}$ & 91,8 & $\begin{array}{c}91 \\
4 \\
\end{array}$ & 95,8 & 93 \\
\hline Manggis & $\begin{array}{c}19.46 \\
7\end{array}$ & $\begin{array}{c}19.46 \\
7\end{array}$ & $\begin{array}{c}19.46 \\
7\end{array}$ & $\begin{array}{c}21.00 \\
0\end{array}$ & $\begin{array}{c}19.00 \\
0\end{array}$ & $\begin{array}{c}18.40 \\
0\end{array}$ & 92,7 & $\begin{array}{c}97 \\
5\end{array}$ & 94,2 & 94,8 \\
\hline \multicolumn{10}{|c|}{ Rata - rata akurasi prediksi untuk 44 komoditi pangan } & $97,41 \%$ \\
\hline
\end{tabular}




\subsection{Pembahasan}

Data yang diperoleh adalah data harga komoditi pangan dari bulan Januari Desember untuk 44 komoditi pangan yaitu IR 64, ciherang, membramo, cimandi, superwin, sintanur, cisantana, pulut hitam, pulut putih, jagung kuning kering, jagung putih, kedelai, kacang tanah, kacang hijau, ubi kayu, ubi jalar, bawang merah, bawang putih, cabe merah besar, cabe merah keriting, cabe rawit, kol bulat, kentang, tomat, wortel, bunga kol, buncis, bawang daun, alpokat, apel merah, apel hijau, jeruk, nangka, mangga, nenas, pepaya, pisang ambon, pisang tanduk, rambutan, salak, langsat, durian, semangka, dan manggis.

Proses prediksi harga komoditi diawali dengan proses training dimana proses tersebut merupakan proses pembelajaran sistem agar sistem dapat mengklasifikasikan harga komoditi pangan. Dari proses training dilanjutkan dengan testing data dimana pada tahapan testing sistem mulai melakukan proses prediksi harga komoditi pangan. Rata - rata akurasi hasil simulasi prediksi harga dari bulan Januari-Maret adalah $97,41 \%$ dengan presentase kesalahan 2,59\%. Untuk 44 komoditi pangan rata-rata prediksi harga data uji dari bulan Januari-Desember adalah $97,92 \%$ dan presentase kesalahan sebesar 2,08\%.

\section{KESIMPULAN}

Berdasarkan hasil penelitian dengan menggunakan metode backpropagation pada prediksi harga komoditi pangan maka dapat disimpulkan :

1. Hasil prediksi fluktuasi harga pasar komoditi pangan di Kota Palu dengan menggunakan metode backpropagation adalah IR 64 Rp7.387, ciherang Rp8.182, membramo Rp8.150, cimandi Rp8.131, superwin Rp8.228, sintanur Rp8.660, cisantana Rp8.122, pulut hitam Rp21.383, pulut putih Rp16.558, jagung kuning kering Rp5.983, jagung putih Rp9.283, kedelai Rp14.600, kacang tanah Rp20.008, kacang hijau Rp16.375, ubi kayu Rp8.225, ubi jalar Rp8.542, bawang merah Rp28.550, bawang putih Rp21.208, cabe merah besar Rp27.308, cabe merah keriting Rp23.650, cabe rawit Rp36.450, kol bulat Rp6.833, kentang Rp12.067, tomat Rp6.108, wortel Rp11.000, bunga kol Rp8.625, buncis Rp10.333, bawang daun Rp25.242, alpokat Rp11.000, apel merah Rp29.023, apel hijau Rp31.067, jeruk Rp6.083, nangka Rp23.483, mangga Rp11.187, nenas Rp8.183, pepaya Rp10.600, pisang ambon Rp8.481, pisang tanduk Rp2.683, rambutan Rp8.450, salak Rp5.625, langsat Rp8.366, durian Rp19.208, semangka Rp14.528, dan manggis Rp18.067. Rata - rata dari prediksi harga komoditi pangan yang didapatkan mengalami kenaikan tiap bulannya.

2. Penerapan metode Jaringan Syaraf Tiruan untuk prediksi harga komoditi pangan dengan model backpropagation dapat bekerja dengan baik dan keakuratan prediksi backpropagation untuk 3 bulan dari januari - maret mencapai $97,41 \%$ dan akurasi pada data uji penelitian ini dari bulan januari-desember tahun 2016 mencapai 97,92\% untuk hasil prediksi fluktuasi harga. 


\section{DAFTAR PUSTAKA}

[1] Kusumadewi, S, Membangun Jaringan Syaraf Tiruan (Menggunakan Matlab dan Excel Link), Graha Ilmu, 2004, Yogyakarta.

[2] Oner, C, Inflationprices on the Rise, 2012, Faculty of Medicine Trakya University.

[3] Soekartawi, Rusmadi dan Damaijati, E, Risiko dan Ketidakpastian dalam Agribisnis Teori dan Aplikasi, PT Raja Grafindo Persada, 1993, Jakarta.

[4] Hsu, C, W, Lin, C, J, A Comparison Of Methods For Multi-Class Support Vector Machines, 2004, IEEE Transactions On Neural Networks, USA.

[5] Sembiring, K, Tutorial Support Vector Machine Bahasa Indonesia, Sekolah Teknik Elektro dan Informatika, 2007, Institut Teknologi Bandung. 